\title{
The Power of the Breast
}

\author{
Jessica Schweifel
}

\begin{abstract}
This piece is about the author's experience of breastfeeding her baby, the amazing revelation of it, the minor trials of their early nursing days, and the magic of her womanly body and its capacity to adjust, nurture, and super nourish another life.
\end{abstract}

The Journal of Perinatal Education, 22(1), 59-60, http://dx.doi.org/10.1891/1058-1243.22.1.59

Keywords: breastfeeding, motherhood

Having always been a small-chested person, I never really put too much emphasis or thought into my breasts. I'll admit, I always appreciated how small they were, that-despite gravity-they stood up all by themselves, that I almost never needed a bra, and that just about every top I ever wanted to wear fit me with ease. Things have changed. Pregnancy and motherhood has transformed my small and subtle chest into actual woman breasts that require a bra and don't always cooperate with my wardrobe. This has been a mildly frustrating transition (and if I come home with one more bra to experiment with, I think my husband may cut me off of the family bank account, although I know he couldn't be happier with my "upgrade"). But besides the superficial quirks of this breast metamorphosis, I am obsessed with my new breasts. I have a breast pride that I never imagined I would ever have. I always thought that breasts were overemphasized and oversexualized, but then I became a breastfeeding mother and realized that breasts are absolutely amazing.

Maybe the cultural obsession with breasts which I never before understood stems back to mothers' milk, flowing through our collective unconscious. There is something richly mystical about mothers' milk. I was formula fed as a baby so I have no way of connecting to it firsthand, but babies who are breastfed into toddlerhood often remember their breastfeeding days with a special fondness. When I see a mama with a healthy and chubby breastfed baby, I feel a kinship with her and I think to myself, "She has miracle breasts too!"

I love that my breasts make milk. I love how much my daughter loves them because she knows that she can rely on them to show up when she needs them most. I love the idea that my milk varies in flavor depending on what I ate that day and that I get to eat an extra helping just to keep the supply up to the demand. I love that the more she nurses, the more I make. And I love that my body is so brilliant that the quality of my milk changes with my baby's growing needs. I know that my breasts will never look the same. I've embraced the fact that I now have a "wife's body," as I like to call it, and not a girlfriend's body

Yes, my body has become a nursery, a place for nurturing and cuddling and feeding and soothing, but it's also a magical land where the milk really does flow like honey, on demand! 


\section{I do believe that there is just as much magic and power in the}

breast as there is in the nutrient-rich milk.

n

Do you have a story that illustrates the power of childbirth, breastfeeding, or motherhood that promotes confidence? We invite you to submit your story for possible publication in The Journal of Perinatal Education. Please send your story or query to Judith Lothian, Associate Editor(Jalothian@aol.com). anymore. You know, a "girlfriend's body" has time to exercise and primp, it hasn't widened and weathered the adventure of birth ... it just has the sparkle of youth. I personally have found that I need to hang on to a few extra pounds just to stay super milky, and that is alright with me. I love my wife body. Yes, my body has become a nursery, a place for nurturing and cuddling and feeding and soothing, but it's also a magical land where the milk really does flow like honey, on demand! What is more amazing than that? I feel grateful that despite all the breastfeeding ailments I experienced throughout the first several months of nursing-everything from mastitis to blebs to thrush to vasospasms to cracked nipples-our nursing relationship is going strong and my milk has persevered. Most people I know think that I am crazy for never having given Veda a bottle. I chose not to give her a bottle until at least 3 months and then 6 months went by. Surely, there were days or nights where I would have loved my husband's support in that department, but I guess I was hooked to an unconscious conviction. I do believe that there is just as much magic and power in the breast as there is in the nutrient-rich milk, and because I decided to be a stay-at-home mama for Veda's first year, it was just easier for me to feed her straight from the source and not have to pump. For those mothers who pump, more power to you because I know how much work and effort it is! Your babies are lucky that you put so much love and time into giving them all you've got. And for the mamas out there who cannot breastfeed for one reason or another but really wanted to, they/ you deserve all the empathy in the world. My brazen pride is some strange delight I take in my body's magic and my baby's connection to it, but a mama who feeds her baby with love is all it's really about at the end of the day.

JESSICA SCHWEIFEL is a mother, integrative life coach, meditation teacher, spiritual counselor, and writer. Currently on leave from all services but mothering, she remains a student of life, Consciousness, Kundalini Yoga, The Shadow, and all things natural and mystical. Jessica lives and works in Brooklyn, New York with her husband and daughter. 